\title{
DESIGN AND FABRICATION OF 360 DEGREE COOLER CUM
} HEATER

\section{Mr. Hemanth Suvarna ${ }^{1}$, Dhanush $\mathbf{R}^{2}$, Ibrahim Khaleel Farooqui ${ }^{3}$, Mohammed Ifraz $^{4}$ and Mulhammed Alfaz ${ }^{5}$ \\ ${ }^{1}$ Sr. Assistant professor, Dept. of Mechanical Engineering, Alva's Institute of Engineering and Technology, Karnataka, India. \\ 2,3,4,5 $8^{\text {th }}$ Sem, B.E Mechanical Engineering, Alva's Institute of Engineering and Technology,} Karnataka, India

\section{Abstract}

To develop the energy efficient, environment friendly direct evaporative air conditioning and forced heating system having low operating cost suitable for hot and dry regions and climates. To manufacture advanced 360 degree rotating air cooler\& heater which rotates and provide air cooling and heating in all directions.360 degree design air cooler\& heater will allow person to sit in any direction during winter for heater and cooler for summer. Simple 360 degree evaporative cooling is achieved by direct contact of water particles \& a moving air stream. When a hot and dry air is allowed to pass through a wet cooling pad, the temperature of incoming air is reduced with an increase in specific humidity as some water from the pad is evaporated taking the latent heat of vaporization from the incoming air.360 degree heater, is forced convective heater that has an electric fan to speed up the air flow. In a convection heater, the heating element heats the air in contact with it by thermal conduction. Hot air is less dense than cool air, so it rises due to buoyancy, allowing more cool air to flow in to take its place. To achieve comfortable temperature either as heater or cooler.

Keywords: Latent heat, specific humidity, convective heater

\section{INTRODUCTION}

The evaporative cooling and forced convection heater is one of the earliest methods employed by men for conditioning their houses. Only in recent years, it has been put on sound footing thermodynamically.

Evaporative cooling is a process of adiabatic saturation of air when a spray of water is made to 360 degree evaporative cooling pads without transfer of heat from or to the surroundings.

Simple 360 degree evaporative cooling is achieved by direct contact of water particles \& a moving air stream. If the water is circulated without a source of heat \& cooling, dry air will become more humid \& will drop in temperature. An evaporative cooler (also swamp cooler, desert cooler and wet air cooler) is a device that cools air through the evaporation of water. Evaporative cooling differs from typical air conditioning systems which use vapor compression or absorption refrigeration cycles. When a hot and dry air is allowed to pass through a wet cooling pad, the cooling pad is made up of wood wool the temperature of incoming air is reduced with an increase in specific humidity as some water from the pads is evaporated taking the latent heat of vaporization from the incoming air.

The air may be sufficiently cooled by 360 degree evaporative process to results a considerable degree of summer comfort in climates of high dry-bulb temperatures associated with low relative humidity. The minimum outdoor temperature required for successful 360 degree evaporative cooling is above $32^{\circ} \mathrm{c}$. The comfort given by the 360 degree evaporative cooling always depends upon the outdoor temperature \& r.h. always gives more comfort with 360 degree evaporative 
cooling. Although the 360 degree evaporative cooling does not perform all the function of true airconditioning but it provides comfort by filtering \& circulating the cooled air. This system does not dehumidify the air but on the contrary, further humidify air.

Before the advent of residential air-conditioning it was the only mechanical means available to make home interiors livable in the hot, dry, desert summers. 360 degree evaporative coolers function well except for the few weeks of the summer "monsoon" season with its accompanying elevated humidity and thus decreased cooler efficiency. These cooling systems are economical in terms of energy usage. During the energy crunches of the last two decades, 360 degree evaporative cooler use was promoted as one means to control household utility bills. However, little thought was given to cooler water consumption. With rapidly increasing population, warm temperatures, and limited water supply, 360 degree evaporative cooler water usage can no longer be ignored.

Heater is process of heating forced air with the help of heatingcoil.360 degree heater, is forced convective heater that has an electric fan to speed up the airflow. They operate with considerable noise caused by the fan. In a convection heater, the heater made of stainless steel the heating element heats the air in contact with it by thermal conduction. Hot air is less dense than cool air, so it rises due to buoyancy, allowing more cool air to flow in to take its place. This sets up a convection current of hot air that rises from the heater, 360degree heater is more use full temperature less than 30 degree Celsius, during the summer season the efficiency of the heater may decrees, the degree heater allowing the hot air to move in360 degree manner and heats up the surrounding space. The initial investment cost of 360 degree cooler and heater is low \&the operation is simple \& cheap.

\section{DESIGN AND CALCULATIONS}

\section{Dimension:}

Frame: length: $50.5 \mathrm{~cm}$ width: $46.3 \mathrm{~cm}$

Frame dimensions 4 sides remain same

Top circular housing: diameter: $53 \mathrm{~cm}$, thickness: $18.4 \mathrm{~cm}$

Flapper blades: 6 blades are there

Width: $13.54 \mathrm{~cm}$, length: $18.4 \mathrm{~cm}$

Water tank: length $57.5 \mathrm{~cm}$, width: $50.5 \mathrm{~cm}$

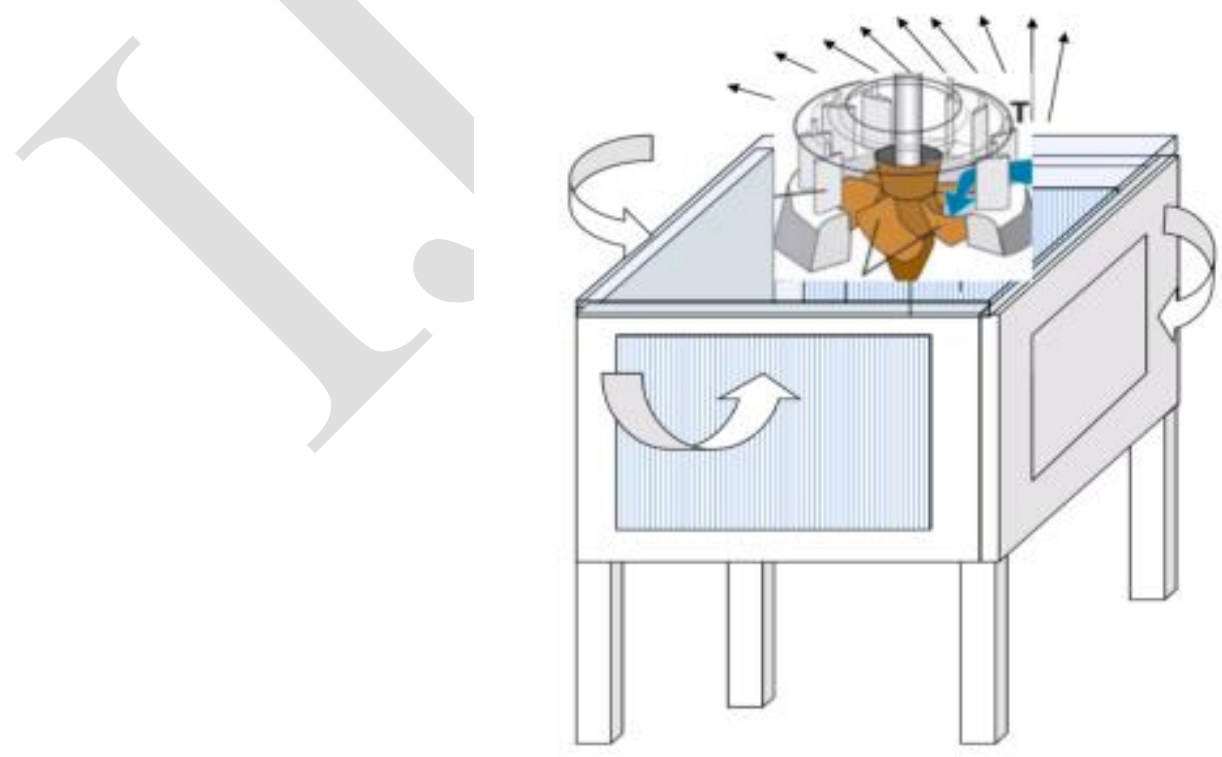

Fig 1:3D view of 360 degree cooler cum heater 


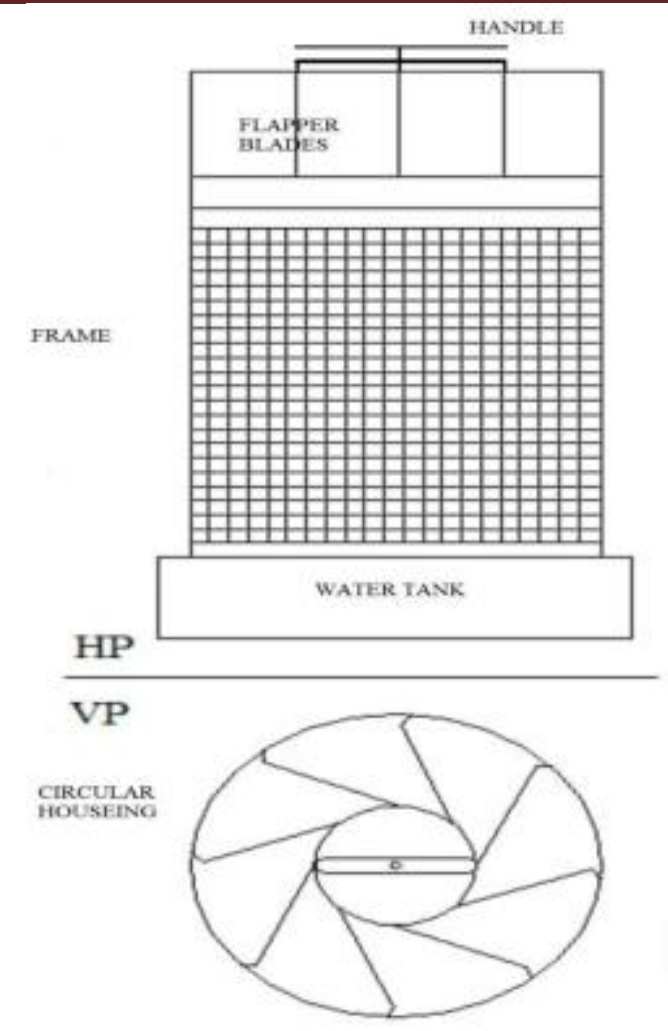

Fig 2:2D view of 360 degree cooler cum heater

Calculations:

CALCULATIONS FOR HEATING:

DATA HANDBOOK AUTHER: C. P. KOTHANDARAMAN AND S. SUBRAMANYAN

Speed of the fan, N=1400 - 2800 RPM

Assume, Velocity of air=Velocity of fan (15\% reduction)

Velocity of fan $=\frac{\pi \mathrm{DN}}{60}$

D- Outer diameter of fan in meter $(0.3 \mathrm{~m})$

$\mathrm{N}$-speed of fan in RPM (2800)

Velocity of fan:

$\mathrm{V}=\frac{\pi \mathrm{x} 0.3 \times 2800}{60}$

$\mathrm{V}=43.982 \mathrm{~m} / \mathrm{s}$

Velocity of air:

Considering $15 \%$ reduction in velocity of fan

Velocity of air $=85 \%$ velocity of fan

$\mathrm{V}_{\text {air }}=0.85 \times 43.982$

$\mathrm{V}_{\text {air }}=37.33 \mathrm{~m} / \mathrm{s}$

We know that, Reynolds number $\operatorname{Re}=\frac{V L}{v}$

$\mathrm{V}$ - velocity of air

L- Thickness of heater coil

$v$ - Kinematic viscosity of air at $26^{\circ} \mathrm{C}$

$\mathrm{Re}=\frac{37.33 \times 0.003}{16 \times 10^{-6}} ; \mathrm{Re}=6999.375$

We know that, Nusselt number $\mathrm{Nu}=\mathrm{C}_{1 \mathrm{x}} 1.1 \mathrm{R}_{\mathrm{e}} \mathrm{xP}_{\mathrm{r}}{ }^{0.33}$ (For noncircular shapes) 
$\mathrm{P}_{\mathrm{r}}$ of air at $25^{\circ} \mathrm{C}$

$\mathrm{C} 1=0.224$

$\mathrm{Nu}=0.22 \times 1.1 \times(6999.375)^{0.612} \times(0.701)^{0.33}$

$\mathrm{Nu}=49.42$

We know that, $\mathrm{Nu}=\frac{h L}{k}$

k- Conductivity of air at $26^{\circ} \mathrm{C}$

L- Thickness of coil

h- Heat transfer coefficient

$49.42=\frac{h(0.003}{0.02658}$

$\mathrm{h}=437.861 \frac{w}{k m^{2}}$

Convective heat transfer, $\mathrm{Q}=\mathrm{hA}\left(\mathrm{T}_{2}-\mathrm{T}_{1}\right)$

\begin{tabular}{|c|c|c|}
\hline $\begin{array}{c}\text { Room temperature }\left({ }^{\circ} \mathrm{C}\right) \\
\mathrm{T}_{1}\end{array}$ & $\begin{array}{c}\text { Load }(\mathrm{w}) \\
\mathrm{Q}\end{array}$ & $\begin{array}{c}\text { Temperature of air at the exit of heater }\left({ }^{\circ} \mathrm{C}\right) \\
\mathrm{T}_{2}\end{array}$ \\
\hline 0 & 250 & 34 \\
\hline 10 & 200 & 37 \\
\hline 20 & 150 & 40 \\
\hline
\end{tabular}

Table 2: temperature at the exit of the heater for different loads.

\section{CALCULATIONS FOR COOLER:}

$\mathrm{Q}_{1-2}=\mathrm{G}\left(\mathrm{C} \mathrm{p}_{\mathrm{air}}+\mathrm{Cp}_{\text {water }} * \mathrm{~W}\right)\left(\mathrm{T}_{2}-\mathrm{T}_{1}\right)$

$\mathrm{Q}_{1-2}-$ Heat transform from water to air

$\mathrm{W}$ - Specific humidity of water

$\mathrm{Cp}_{\text {air }}=1.005 \mathrm{kj} / \mathrm{kg}^{\circ} \mathrm{C}$

$\mathrm{Cp}_{\text {water }}=1.88 \mathrm{kj} / \mathrm{kg}^{\circ} \mathrm{C}$

$\mathrm{W}=0.014$ at $32^{\circ} \mathrm{C}$

$\mathrm{G}=3.9729 \times 10^{-3} \mathrm{~kg} / \mathrm{sec}$

$\mathrm{Q}_{1-2}=3.9729 \times 10^{-3} \times(1.005+1.88 \times 0.014)(27-32)$

$\mathrm{Q}_{1-2}=-0.0205 \mathrm{kj} / \mathrm{kg}$

$\mathrm{Q}_{1-2}=-20.5 \mathrm{j} / \mathrm{kg}$

\section{COMPONENTS USED}

\begin{tabular}{|l|l|l|l|}
\hline Sr.no. & $\begin{array}{l}\text { name of } \\
\text { component }\end{array}$ & Specification & Material \\
\hline 1 & Blower motor fan/exhaust fan & $2800 \mathrm{rpm}, 230 \mathrm{v}$ single phase & Std \\
\hline 2 & Pump Under water & pump 230 vsingle phase & Std \\
\hline 3 & Heating coil & $800 \mathrm{w}, 12 \mathrm{amps}$ & Stain less steel \\
\hline
\end{tabular}

Table1: components used and its specification 


\section{FABRICATION WORK}

This is the first step taken to manufacture a frame, water tank, and circular housing The size of equipment is determined as per required size of the room to be cooled or heated ccooling pad dimensions as per the design.

The main components like pump, fan and heating coil are chosen based on design calculations

For cooling the water is used as refrigerant. Fan is used to drive the cool air to the environment and drive less humid air to the heater.

Distance between the fan and heating coil is less ids just avoid the expansion of air, as the air moves from heater to the fan All the four side of the frame is encompassed from the wood wool cooling pad inside, the pads are then sent with the water from the water tank kept bottom the equipment and the water is pumped with the help of pump.

The flapper blade is below the circular plate and this used to drive the cool or hot air to the surroundings in all directions.

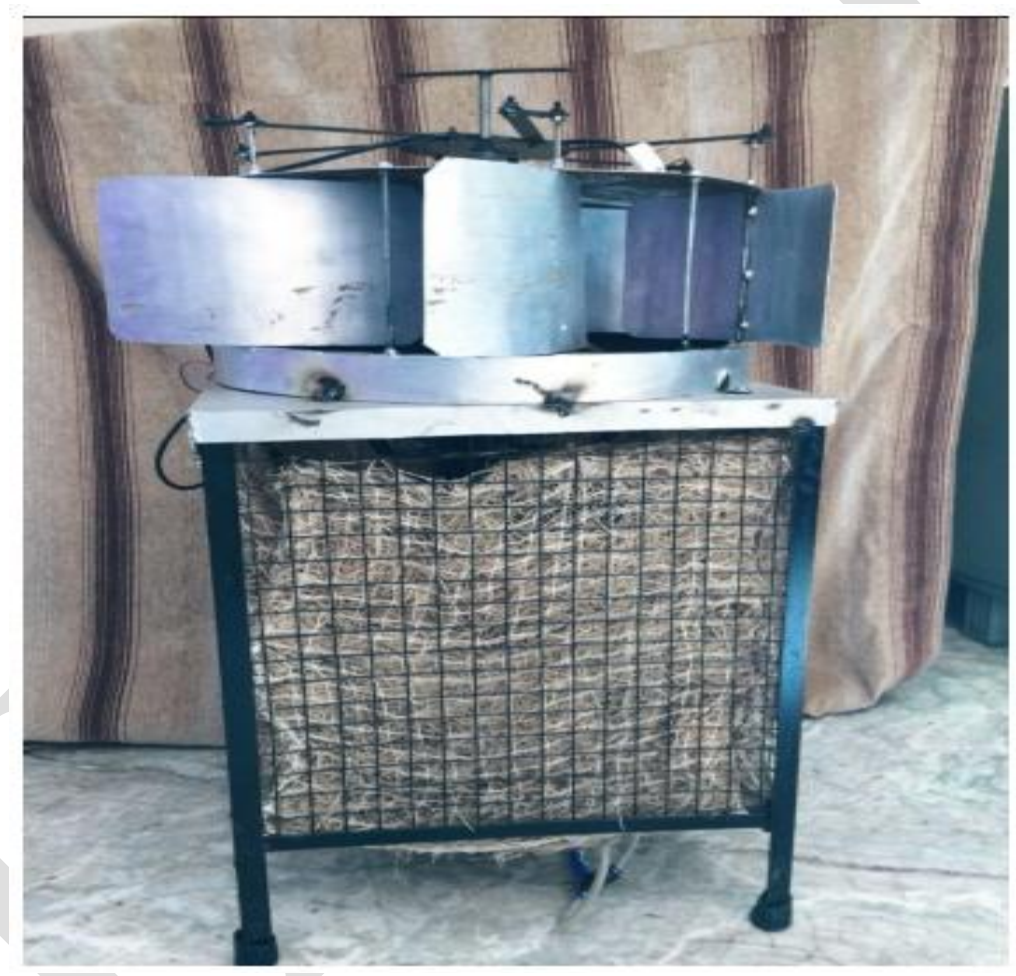

Fig 3:360 degree cooler cum heater

\section{TESTING}

Test duration: 60 minutes

1) HEATER:

Convective heat transfer, $\mathrm{Q}=\mathrm{hA}\left(\mathrm{T}_{2}-\mathrm{T}_{1}\right)$

\begin{tabular}{|c|c|c|c|}
\hline $\begin{array}{c}\text { Initial room } \\
\text { temperature }\left({ }^{\circ} \mathrm{c}\right)\end{array}$ & Load(watts) & $\begin{array}{c}\text { Temperature of air at } \\
\text { The exit of heater }\left({ }^{\circ} \mathrm{c}\right)\end{array}$ & $\begin{array}{c}\text { Final } \\
\text { room } \\
\text { temp }\left({ }^{\circ} \mathrm{c}\right)\end{array}$ \\
\hline 25 & 300 & 68.2 & 28.4 \\
\hline 25 & 250 & 60.3 & 28.1 \\
\hline 25 & 200 & 53.6 & 26.8 \\
\hline 25 & 150 & 46.8 & 26.2 \\
\hline
\end{tabular}

Table 3: final room temperature for different loads. 
2) COOLER:

\begin{tabular}{|c|c|c|}
\hline Time interval $($ mins $)$ & Initial room temp $\left({ }^{\circ} \mathrm{c}\right)$ & Final room temp $\left({ }^{\circ} \mathrm{c}\right)$ \\
\hline 0 & 32 & 32 \\
\hline 10 & 32 & 31.6 \\
\hline 20 & 31.6 & 30.8 \\
\hline 30 & 30.8 & 30.1 \\
\hline 40 & 30.1 & 29.5 \\
\hline 50 & 29.5 & 28.8 \\
\hline 60 & 28.8 & 28.3 \\
\hline
\end{tabular}

Table 4: final room temperature different interval of time.

\section{ADVANTAGES OF 360 DEGREE COOLER CUM HEATER}

Today's world, though air conditioners and heater are in most of the places, air cooler cum heater have their advantages and importance. It is a new concept also There are many advantages

- Easy to operate: Any tube of cooler is composed of mainly two parts Fan \& Pump. There are no complicated parts as in Air conditioners. Only3 switches, one for fan and other for pump motor are to be operated and switch is for heater.

- Easy to clean: Cooler cum heater are to be filled with water before operating. For this any one door is to be removes. Hence person can clean the base tank easily with any cloth. The pads do not need cleaning. They are to be replaced after every two years of frequent use.

- Less power consumption: Power consumption in air coolers is many times lesser than air conditioners since no compressor or other complicated circuits are used.

- Cheaper: Air coolers and heater do not have expensive components and hence are cheaper on cost.

- Maintenance: Maintenance cost is nearly negligible. Only the cooling pads are to be replaced after every two years, which are very cheap. If the motor of the pump gets damaged, they can be repaired cheaply.

- Easy installation of different parts: If the pump or fan or any other part is damaged, these can be easily replaced by any person.

\section{CONCLUSION}

From the present investigation it is evident that for drip type 360 degree evaporative cooler cum heater performance characteristics cooling the performance characteristics can be related to the variables like and thickness and the atmospheric conditions such as humidity control and comfort. It is also possible to determine the parameters but location and one need to optimize the design parameters for corresponding outdoor conditions.

The result also indicates that a considerable saving in power consumed is possible and at the same time the cooling effectiveness can be enhanced. The procedure detailed in the present study can be used to advantage in designing 360 degree cooler cum heater of larger capacity to economically cool bigger endorsers, because the various parameters can be changed with ease The approach can be employed to analyze any piece of equipment and improve its performance.

\section{SCOPE FOR THE FUTURE WORK}

Every machine has scope for its future work and modification for gaining more and more beneficial output with the least input. Hence human is always trying for achieving it. Being technology it comes under the research and development activity. Our product being the small and compact one, still it has so many scopes for its future developments as following:- 
1) We can install thermostatic expansion valve for auto cut off for the heater coil, so that the temperature of the heater coil can be set at the required and the desired value as per the temperature conditions.

2) We can regulate the capacity of the blower fan by installing potentiometer so that as per the requirement the flow of air can be regulated.

3) The water level indicator can be installed so that the level of water can be easily detected and maintained.

4) The tank material can be replaced by stainless steel to save it from the environmental corrosion and erosion.

5) The front side air diverting strips mechanism can be made auto diverting as well as manually operated by coupling the lever using belt and pulley drive.

6) The temperature can also be controlled by controlling and regulating the speed of the pad roller and drive motor.

\section{REFERENCE}

I Manufacturing of 360 Degree Rotation Air Cooler Sunil J.Kavle, Vivek M. Shahane, Nivrutti Satpute, Vitthal N. Garje. Guide Prof. Shrikant D Jadhav

II Sharief Sn, Anhil T, Khurshid "A Home Made Air Conditioning Unit".

III Kalwa V, Prakash R. "Modelling And Fabrication of Solar Powered Air Cooler With Cooling Cabin For Household Food Items". International Journal of Mechanical Engineering and Robotics Research. 2014 Jul 1;3(3):45.

IV Vishalm Barde, Govind R Bathe, Tusharh Borde, Akash G Bhore, Prof. Swapnilumale "Modification and Development in Air Cooler".

V Applied Thermodynamics By P K Nag. 